\title{
UM OLHAR SENSÍVEL SOBRE O PAPEL DOS ESPAÇOS LIVRES DE UMA ESCOLA PÚBLICA E SEU ENTORNO NO MUNICÍPIO DE QUIXADÁ/CE
}

\section{A SENSITIVE LOOK ABOUT THE ROLE OF THE PUBLIC SCHOOL'S OPEN FREE SPACES AND ITS ENVIRONMENT IN QUIXADÁ/CE}

MARTINS, DIEGO FREIRE.

Graduando em arquitetura e urbanismo, LOCl - Grupo de estudos em Qualidade do Lugar - Centro Universitário Católica de Quixadá/CE, diego_freire@live.com

\section{GERSON, GISELLE CERISE}

Doutoranda do PROARQ-UFRJ, LOCI - Grupo de estudos em Qualidade do Lugar - Centro Universitário Católica de Quixadá/CE, gisellecerise@gmail.com

\section{RESUMO}

O sistema educacional não possui mais uma hegemonia educativa, levando em consideração as inúmeras fontes de aprendizagem da atualidade que contribuem para a formação humana. Dessa forma, optou-se por investigar espaços com potencial educativo que favorecem a socialização dentro e fora da escola. 0 estudo está dividido em duas escalas: a urbana por meio dos espaços livres públicos como ruas, praças e vazios urbanos; e a escala da escola por meio de suas áreas livres. Assim, tem-se como objetivo compreender a relação entre a configuração dos espaços livres públicos e comportamento dos alunos de uma escola pública e seu entorno. Para tanto, a pesquisa possui uma abordagem experiencial e está estruturada em revisão de literatura com uma aproximação sobre a relação entre educação e cidade; e Estudo de Caso, ao escolher uma escola pública municipal na periferia do município de Quixadá/CE, onde houve aplicação dos instrumentos metodológicos - o mapa cognitivo, mapa comportamental e poema dos desejos -, a fim de compreender a percepção dos alunos sobre a escola e o bairro, suas preferências ambientais quanto às escolhas dos lugares de recreação e como acontece a apropriação destes nas áreas livres da instituição, nos trajetos casa-escola. Os resultados encontrados mostram que os espaços livres da escola podem se transformar no elemento integrador entre escola e comunidade e que entender a escola e seu entorno como possibilidades de aprendizagem é uma forma de complementar a formação humana através da promoção de espaços de estímulo à socialização, à autonomia e à cidadania.

PALAVRAS-CHAVE: espaços livres públicos; escola pública; preferências ambientais; abordagem experiencial.

\section{ABSTRACT}

The educational system does not have an educational hegemony anymore, taking into account the large amount of source for learning of the present time that contributes to the human formation as a citizen. Thus, we decided to investigate spaces with educational potential that support socialization in and out of school. This study is divided in two scales: the urban through the public free spaces like streets, squares and open spaces; and the school scale through its free areas. Thereby, has a objective to understand the relation between configuration on the Public open free spaces and students behavior in a public school and its environment. Therefore, the research that an experiential approach and its structure in literature review with a approximation about the relation among school and city; and Case Study, the choice of a municipal public school in the outskirts of the city of Quixadá/CE, where there was application of methodological instruments - the cognitive map, behavioral map and poem of wishes, in order to comprehend the students perceptions about the school and the neighborhood, their environmental preferences regarding the choices of the places of recreation and how the appropriation of these institution's free areas happens, in the home-school pathes. The results found was that the school's free spaces can become in the integrator factor between school and community and that to understand the school and its environment as learning possibilities is a way of complementing the human formation through of promotion for more human spaces, of incentive of autonomy and citizenship. KEYWORDS: public open free spaces; environmental preferences; experiential approach. 


\section{INTRODUÇÃO}

A hegemonia do sistema educacional enquanto único veículo eficiente de aprendizagem e formação do ser humano é um mito em nossa sociedade. Pode-se afirmar que existem inúmeras formas de se aprender e de se constituir a formação humana, como defende o educador Freire (1996), dentre elas, atualmente é inegável a influência promovida pela convivência em grupo ou pela mídia, por meio do acesso à internet ou à televisão, entre outros (FARIA, 2017). Essas diferentes formas de aprender podem ser categorizadas como uma educação não formal, entendida por Gadotti $(2005$, p.2) como mais difusa, não regida por um sistema e com duração variável. Ela acontece ao contrário da educação formal, cuja estrutura depende de uma diretriz educacional, como o currículo, e é desenvolvida de maneira mais burocrática, como acontece nas escolas e universidades. De fato, ambas as formas de educação devem ser encaradas como complementares, pois se considera que hoje em dia é impossível excluir ou ignorar esses diversos aspectos da aprendizagem.

Assim, a pesquisa optou por investigar espaços com potencial educativo que favorecem a convivência e a socialização dentro e fora da escola, entendendo-se como áreas livres públicas da cidade aquelas que, reconhecidamente, viabilizam a vivência coletiva, definidas por Pizzol (2005) como espaços livres não edificados.

Com o propósito de conservar a clareza do estudo, o mesmo foi dividido em duas escalas: a urbana, por meio dos espaços livres públicos, (ruas, passeios, praças e terrenos livres urbanos); e a escala da escola, por meio de suas áreas livres. No contexto das formas de aprender defendidas por Gadotti (2005), a pesquisa buscou o encontro destas duas escalas, considerando a inserção da escola na vida urbana por meio da socialização e da apropriação dos espaços livres pela comunidade. Contudo, para se atingir a complementaridade entre as escalas supracitadas, recai-se sobre alguns problemas que dificultam ou a inviabilizam. Um deles é o abandono ou subutilização dos espaços livres, em que seu estado físico ruim de conservação ou um distanciamento destes em relação às necessidades dos usuários, resulta no desinteresse das pessoas.

Assim, a principal indagação norteadora da presente pesquisa foi: Como é a percepção ambiental das crianças sobre os espaços livres dentro e fora de uma escola pública, suas formas de recreação, socialização, deslocamentos e preferências ambientais? Chegou-se, assim, ao principal objetivo da investigação, que foi compreender a relação socioambiental entre a configuração dos espaços livres e o comportamento dos alunos de uma escola pública e seu entorno.

A pesquisa foi realizada no contexto de uma escola pública de ensino fundamental, tendo como público-alvo as crianças de 09 à 12 anos. Seus objetivos específicos foram: caracterizar a escola escolhida e seu entorno; analisar a percepção, as formas de apropriação e as preferências ambientais dos usuários da escola pública selecionada e seu entorno.

O estudo desenvolveu-se no município de Quixadá, localizado na região do Sertão Central cearense, distante cerca de $150 \mathrm{~km}$ da capital do estado. A principal razão de escolha parte do registro do rápido crescimento urbano, que gera o surgimento de bairros periféricos e da representatividade que o município possui em relação à educação. Foi realizado um recorte espacial na cidade numa área que compreende parte dos bairros Campo Novo e Putiú, pois se apresentam como periféricos e possuem alta taxa de densidade demográfica. A área possui quatro escolas públicas, dentre elas, foi selecionada uma escola pública municipal de ensino fundamental I, pois apresenta uma faixa-etária de crianças de 09 à 12 anos, que já estão, de acordo com os estudos de Oliveira (2004) em um estágio considerável de alfabetização, de tendência à autonomia e a socialização.

Quanto ao percurso metodológico a pesquisa está dividida em três etapas gerais, são elas: (1) composição do referencial teórico, (2) análise da área e (3) interpretação dos resultados. Na primeira etapa foi elaborado um levantamento bibliográfico a fim de realizar uma aproximação sobre a relação entre educação e cidade. Em seguida, foi feita uma discussão sobre os espaços livres públicos e sua importância na formação da cidadania, principalmente, das crianças. Como último ponto de debate, fundamenta-se a escala das áreas livres da escola como áreas com potencial educativo e de contribuição à socialização e a recreação das crianças.

Na segunda etapa, produziu-se uma análise da área através de uma breve caracterização do contexto urbano que o equipamento escolar está inserido. Foram observados os aspectos físicos, como hierarquia de vias, elementos estruturantes e uso do solo urbano.

Logo após, buscou-se a aplicação em campo de uma abordagem experiencial definida por Alcântara (2008, p.11) como uma observação que incorpora as interações homem-ambiente, "enriquecendo e conferindo novo significado ao entendimento do lugar". Desse modo, foram utilizados três instrumentos metodológicos: mapa cognitivo, poema dos desejos e mapa comportamental. Estes foram aplicados com as crianças de idades que variam de 09 a 12 anos. 
O mapa cognitivo é um procedimento desenvolvido por Kevin Lynch e tem por objetivo compreender como o usuário ou um grupo entende e percebe uma determinada área. Este instrumento foi utilizado para identificar os principais caminhos dos alunos à escola e observar se existem marcos ou características mais relevantes que se repetem. Posteriormente, foi aplicado o poema dos desejos ${ }^{1}$, para registrar as necessidades, sentimentos e desejos sobre a escola através de desenhos ou textos, com enfoque nos lugares que as crianças mais gostavam e o que elas desejariam para a instituição.

Para avaliação dos espaços livres da escola foi usado o mapeamento comportamental, que é uma forma de registro empírico que visa identificar a percepção dos usuários sobre um ambiente (RHEINGANTZ et al, 2009). A utilização deste teve por finalidade avaliar quais os usos, as formas e modos de apropriações das crianças nos espaços livres da escola.

\section{UMA APROXIMAÇÃO ENTRE EDUCAÇÃO E CIDADE}

O diálogo entre escola (educação formal) e o seu entorno (educação não-formal) através dos espaços livres da cidade vai de encontro às discussões de Azevedo et al $(2015$, p.2), ao dar continuidade aos pensamentos e propostas de Anísio Teixeira. Sendo este debate uma forma de encarar os dois tipos de educação como complementares e indispensáveis, a partir do reconhecimento de que é possível potencializar e enriquecer uma a outra.

Segundo Faria (2017) a formação do sujeito é inseparável do ambiente que o circunda; essa postura é essencial para a relação entre educação-comunidade (entorno), por meio da educação promovida nos espaços da cidade, tornando-a um lugar de relações humanas e a visão da educação como um processo amplo e multiforme de socialização. Com essa postura, o aluno, ao mesmo tempo, que aprende na cidade, também humaniza o espaço urbano se tornando um lugar apropriado e, por conseguinte, pertencente a este.

Para Gadotti (2005, p.6), a cidade pode ser intencionalmente educativa, quando além de "cumprir as funções tradicionais - econômica, social, política e de prestação de serviços - ela exerce uma nova função: a formação para e pela cidadania".

Consoante aos estudos de Gadotti (2006) em sua obra "A escola na cidade que educa", a comunidade deve integrar a escola ao novo espaço cultural da cidade. A escola passa então a não ser um lugar abstrato, pois se propõe a inserir-se na vida da cidade. Ela acaba por se transformar num novo território de construção da cidadania. Desse modo, os espaços livres públicos ${ }^{2}$, tornam-se essenciais nessa articulação e integração entre a escola e seu entorno (comunidade).

\section{Espaços livres públicos e sua importância na formação da cidadania}

A formação cidadã perpassa pela apropriação dos espaços da cidade, para que se desenvolva o sentimento de pertença; no caso da criança, conforme defende Oliveira (2004, p.88), devem ser criados mecanismos educacionais que integrem experiências de vida aos laços sociais das crianças; pois servirão como paradigma para transmitir os valores, crenças e ensinamentos que constituem a formação humana.

Gehl (2013) acredita que os espaços públicos são, reconhecidamente, locais de convivência e destinados ao uso coletivo. Nessa linha de pensamento, Oliveira (2004, p.86) afirma que caso as crianças não utilizem esses espaços, como consequência, irá prevalecer o isolamento, os interesses e ações individuais. Resulta-se assim, em relações sociais frágeis.

Portanto, o ato de reunir-se nos espaços públicos, ajuda a criança a desenvolver sua cidadania, a partir da compreensão desta como pertencente a um grupo social e que esse ato significa exercer sua responsabilidade com relação ao que é comum (OLIVEIRA, 2004). Transformando-se numa reprodução que respeita a sociabilidade e institui o social.

Uma das formas mais comuns de interação da criança com um grupo social se dá através da recreação e do lazer por meio do lúdico, sendo estes alguns dos principais métodos para seu desenvolvimento. O lúdico oferece suporte nos campos pessoal e educativo das crianças, ao possibilitar que, ao mesmo tempo em que elas brinquem, também aprendam.

Nascimento $(2009$, p.41) trata das contribuições da criança ao sujeito arquiteto em seu processo criativo, e defende que o brincar se caracteriza como um ato de liberdade e de vontade, pois para a criança não há diferença entre brincar e fazer coisas sérias. A brincadeira acaba por tornar-se o que ela faz de mais sério. É através disso que elas demonstram, inclusive, a leitura que fazem da sociedade em que vivem, revelando a apreensão de traços culturais desta; por exemplo, ao brincar de "casinha", as crianças imitam e, naturalmente, fazem uma releitura sobre o que presenciaram ou viveram na família, viram na televisão ou outros meios. 
Com isso, a criança tem a necessidade de atuar, irremediavelmente, em um espaço físico adequado para seu pleno desenvolvimento através do lúdico, pois eles são substanciais no processo de construção da autonomia e de formação da criança (OLIVEIRA, 2004). Ao vivenciar o espaço público sozinha ou sob a supervisão de um adulto, por exemplo, a criança passa a conviver com a diferença, ao passo que tem mais chances de tornar-se um adulto que respeita a cidade e seus comuns.

Caso não haja a vivência da criança no espaço público, Dias e Ferreira $(2015$, p.126) apontam que é criado um distanciamento da criança em relação à cidade. Isso faz se estabelecer um paradigma do medo e acentua a infantilização em oposição a uma infância saudável, em que "as crianças tornam-se mais dependentes dos adultos e desinteressadas em descobrir, por si mesmas, o que o mundo thes oferece para ser explorado, percebido, sentido e vivenciado". Para as autoras, tem como consequência a criação de "cidadãos incapazes de interferir na organização de uma sociedade mais consciente, democrática e harmônica".

Oliveira (2004, p.175) diz que o espaço público deve ser pensado como estrutura da cidade, e não como espaço residual, "Ele deve ajudar a romper a barreira da exclusão, situando-se em locais que colaborem para o bem-estar da criança que, normalmente, vive em espaços muito reduzidos", principalmente as crianças das classes populares, que sem opções de brincadeira ou ocupação em casa, vão para a rua preencher esse ócio. No entanto, elas usufruem de um espaço que se tornou deserto por falta de convívio social ou do encontro com a diferença. Eles se encontram degradados, como resultado, acontece um distanciamento das pessoas.

É substancial que a criança vivencie o contexto urbano de forma adequada, a fim de construir e exercitar a sua cidadania coletiva. Segundo Dias e Ferreira (2015, p. 128) pode-se viabilizar a prática da cidadania no coletivo a partir da "integração em processos participativos e decisórios da vida urbana, a disponibilidade, o uso coletivo e a apropriação dos espaços públicos urbanos, assim como a identificação das crianças com tais espaços". Ao utilizar cotidianamente espaços como estes, as crianças poderão se tornar, de acordo com os estudos de Dias e Ferreira (2015, p. 128), "menos individualistas, mais tolerantes e saudáveis, mais responsáveis e conscientes de que o bem coletivo se configura, também, como o bem de cada um". Nutre-se assim, a ideia de uma sociedade mais equitativa, harmônica, que cultiva o respeito e a tolerância, de todos e para todos.

\section{Acessibilidade e inclusão social nos espaços livres públicos}

$\mathrm{O}$ acesso à cidade é um direito básico de todos os habitantes. Com isso, todos os espaços livres possuem a necessidade de estarem adequados e acessíveis à todos. A Associação Brasileira de Normas Técnicas (ABNT), através da NBR 9050/2004 define que acessibilidade é a "Possibilidade e condição de alcance, percepção e entendimento para a utilização com segurança e autonomia de edificações, espaço, mobiliário, equipamento urbano e elementos".

De acordo com o arquiteto-pesquisador Grinover (2006, p.38) adota-se o conceito supracitado como referente a uma acessibilidade física e tangível, porém, para o autor, há um tipo de acessibilidade que é intangível: "trata-se da acessibilidade à cultura, à informação que pode se dar pela possibilidade da população da cidade ou de estranhos, ter condições de frequentar uma escola, um curso, um sistema de lazer".

Ambos os conceitos se alinham à cidadania, pois "a essência da cidade é justamente o estímulo à aproximação entre seus habitantes, o que cria as condições para a interação social e define o espaço urbano como público, acessível, lugar das diferenças, da heterogeneidade" (GRINOVER, 2006).

A partir de uma perspectiva arquitetônica do ambiente construído, para se ter uma cidade com o mínimo de acessibilidade, Almeida et al (2013, p.3) afirma que "deve-se respeitar a diversidade física e sensorial entre as pessoas e as modificações pelas quais passa o nosso corpo, da infância à velhice", deve-se pensar sempre na "inclusão de rampas, calçadas mais largas, sinalização nas calçadas para deficientes visuais, sinaleira para pedestres e ciclovias", dentre outros.

Dessa maneira, no contexto escolar, Elali (2002) defende que o espaço físico impacta diretamente o aluno, ao passo que este ambiente se torna um inibidor ou facilitador do comportamento. Assim, deve-se construir um espaço que permita e, com isso, potencialize diversos usos por todos, independente de características individuais.

O presente estudo, no entanto, propõe a expansão da concepção de acessibilidade para além dos já abordados anteriormente, apoiado no urbanista Gehl (2013) em sua obra "Cidade para pessoas", quando se propõe a debater a necessidade de se construir cidades vivas, seguras e sustentáveis. Existe uma estreita relação entre se promover uma cidade acessível do ponto de vista físico da legislação e uma cidade que prioriza as pessoas. Para Gehl (2013) os espaços públicos precisam oferecer proteção, segurança, um espaço razoável, mobiliário e qualidade visual. Em outras palavras, não adianta somente que tenha a 
presença de rampas ou uma boa sinalização, é preciso que seja convidativo, ou seja, que se torne um lugar onde as relações acontecem cotidianamente.

\section{O lugar do pátio e das áreas livres da escola como espaços de socialização}

Após o levantamento bibliográfico realizado acima destinado a discutir o contexto dos espaços livres públicos na escala urbana, torna-se necessário debater como estas áreas livres se configuram na escala da escola. Destaca-se a figura do pátio no âmbito das áreas livres escolares. O autor Reis-Alves (2005) considera o pátio como um espaço de transição, uma espécie de átrio que liga a parte externa pública (cidade) a um ambiente interno privativo e aponta que é nele que o homem pode "desenvolver as suas atividades ao ar livre, abraçado pelo edifício".

O edifício escolar é um dos principais programas arquitetônicos que tem o pátio como elemento fundamental de sua composição. Ele está inserido, programaticamente, no conjunto de ambientes de vivência e assistência da escola, sendo defendido por Reis-Alves (2005) como espaço "onde as emoções libertam-se, não há um controle rígido dos comportamentos, das ações”. Para Martins (2013, p.6) o pátio é um espaço livre, de caráter urbano, que tem relação com a permanência, seja de origem público ou privado.

Com o aumento da violência urbana e precarização dos espaços livres públicos das cidades, os pátios escolares se tornaram para Martins (2013, p.1) "os únicos espaços livres que as crianças têm contato no seu dia-a-dia, e na maior parte dos casos, esses espaços não possuem condições de uso e qualidades ambientais que atendam as expectativas e necessidades de seus usuários". Já para Azevedo et al (2011, p.55) o pátio se configura como o primeiro estágio de socialização da criança, ao estabelecer padrões de troca e convívio; "condicionados pela configuração física da edificação escolar, pelo contexto de inserção, pela forma de gestão, pelas diretrizes pedagógicas e pelo perfil sociocultural da população atendida”.

Dada à relevância do pátio escolar enquanto área interna de convivência e de possibilidades pedagógicas para além da sala de aula, é possível afirmar que este possui seu papel no processo formativo dos estudantes. No entanto, geralmente este ambiente é entendido como de importância secundária, por geralmente ser tratado apenas como local para que as crianças fiquem em horários que não têm aula.

Na maioria das vezes, os horários entre as aulas são os mais aguardados pelos estudantes, ao considerar a visão da sala de aula como local disciplinador e o pátio como sinônimo de liberdade proposto por Reis-Alves (2005). Assim, surge o reconhecimento de que é preciso compreender como se dão as relações pessoaambiente no pátio escolar que o tornam atrativos.

A fim de compreender como se dá essa relação pessoa-ambiente, é preciso, primeiro, assimilar que o meio ambiente exerce uma influência direta no indivíduo. Essa influência é depreendida de diversas formas, a depender da percepção do usuário em que a "a percepção humana do espaço passa por um processo de regulação de distâncias, que podem ser pessoais ou sociais, e consideram-se as influências e regras culturais, a sensação de medo ou segurança que o ambiente oferece" (KOWALTOWSKI, 2011).

Kowaltowski (2011, p.30) fala que "a percepção do espaço ocupado pode influenciar a escolha voluntária da posição que o usuário ocupa no ambiente, (...) e as interferências que realiza no espaço físico". Todos estes conceitos resultam na ideia de apropriação que é citado por Martins (2013, p.8) por meio do seu significado em língua inglesa, Place Attachment, que significa "lugar; apego, pertencimento, conexão, possuindo carga simbólica e afetiva na relação entre o indivíduo e o local". A autora entende que, portanto, apropriação é "um processo perceptivo, cognitivo e experiencial produzido nas relações homem-ambiente - compreendido em suas dimensões física, simbólica e cultural".

Enquanto isso, Savi e Rech (2015, p.5) defendem que as formas de interação entre sujeitos e lugares - entre a criança e o pátio escolar - não possuem uma dimensão apenas física, mas uma relação carregada de sentido e mediada pelos sujeitos que ocupam o ambiente. Dessa maneira, ela volta-se ao conceito de apropriação do lugar num contexto de preferências ambientais, de apego, da criação de um sentido ao usar o local. Por isso, mais do que pensar as áreas livres e pátios escolares na sua dimensão física superficial, é preciso considerar aspectos de necessidades formais, estéticas e de criação de um ambiente agradável, que prioriza o bem-estar e o desenvolvimento do aluno.

Se houver uma falta de harmonia entre os componentes do ambiente (mobiliário, pavimentação, dentre outros) com a apropriação espacial dos estudantes, podem-se gerar obstáculos, comprovando o desajuste entre o ambiente e o uso através do padrão de comportamento. Desse modo, o pátio escolar perde, enquanto espaço de socialização e de participante do desenvolvimento humano por meio da recreação e do lazer (SAVI, $\mathrm{RICH}, 2015)$.

Portanto, a análise das relações pessoa-ambiente no pátio escolar é capaz de oferecer subsídios para compreensão das qualidades e deficiências do ambiente construído em relação a este ser palco da 
convivência e das brincadeiras entre os estudantes. A presente pesquisa entende o pátio como a porta de entrada da escola para a cidade. Por essa razão, estudar suas dinâmicas e configurações se apresenta como uma tentativa de integrá-lo ao tecido urbano de maneira a minimizar os limites entre os muros da escola e a comunidade.

\section{CARACTERIZAÇÃO DA ÁREA ANALISADA}

O município de Quixadá, na região do Sertão Central cearense, possui fortes aspirações educacionais, ao se configurar atualmente como um centro de convergência educacional de nível superior na região, com a presença de 06 instituições, entre públicas e privadas. O sistema educacional superior é responsável pela intensificação das relações interurbanas regionais, o que resulta em mudanças espaciais, econômicas e sociais na cidade (HAIASHIDA, 2014).

Num primeiro momento, buscou-se realizar um mapeamento das quase 30 escolas públicas e privadas no perímetro urbano de Quixadá, com o auxílio do Plano Diretor de Desenvolvimento Urbano (PDDU, 2000). O objetivo foi compreender como esses equipamentos estão distribuídos espacialmente e a presença no seu entorno de espaços públicos recreativos, como praças; os equipamentos públicos voltados para usos esportivos (quadras poliesportivas, estádio, etc); culturais (bibliotecas, museu); sociais (Centro de Referência de Assistência Social - CRAS, entre outros) e institucionais (universidades, igrejas). A principal conclusão da análise foi de que existe uma concentração de infraestrutura nas áreas centrais. Já os bairros periféricos apresentam, em sua maioria, uma carência de equipamentos recreativos.

Dessa maneira, por fins de viabilização da pesquisa, foi realizado um recorte espacial de uma área no município conforme os critérios: localização periférica; presença de maior densidade demográfica e o maior número de escolas públicas. A opção por uma área periférica está estruturada em dois motivos: o de que geralmente, os alunos das escolas são oriundos do próprio bairro e que há uma baixa presença de espaços e equipamentos públicos em regiões mais periféricas da cidade, como observado no mapeamento.

O estudo foi desenvolvido numa área que compreende os bairros Campo Novo e o Putiú na cidade de Quixadá-CE. Eles possuem juntos, aproximadamente, 09 mil habitantes segundo estimativa do IBGE (2010) para o ano de 2016; ambos se encontram distantes do centro da cidade cerca de $2 \mathrm{~km}$. De acordo com o Plano Diretor do município, os dois bairros estão inseridos numa área de estímulo para expansão urbana.

Quanto ao sistema viário dos bairros, as vias são, majoritariamente, locais, tendo apenas uma via arterial (Rua Presidente Vargas) que liga o centro da cidade à CE - 122 com acesso ao município de Quixeramobim (Figura 1). As vias locais no tocante à morfologia são, em geral, estreitas e de pavimentação em paralelepípedo, já a única via arterial é de pavimentação asfáltica de duas faixas, sendo mão dupla. Os principais elementos estruturantes foram considerados àqueles que influenciam a dinâmica dos bairros, por exemplo, o estádio municipal de futebol ou áreas que possuem importância paisagística, como o Rio Sitiá que fica próximo da território investigado.

O uso do solo urbano é, predominantemente, residencial como afirma o zoneamento estabelecido pelo Plano Diretor de Quixadá (2000). A área também apresenta alguns pontos de comércio local, sendo simultaneamente residencial e parte comercial, o reconhecido uso misto. Neles, existe uma diversidade de comércio e serviços, porém são de pequeno porte, o que caracteriza um comércio voltado apenas ao bairro. Um fato a ser destacado é que estes pontos estão bastante concentrados na Rua Presidente Vargas, via que liga o bairro ao centro da cidade e a saída para o município vizinho, Quixeramobim. Outra característica da área é a baixa presença de equipamentos recreativos, como praças ou parques urbanos, registrou-se a presença de apenas uma pequena praça. 
Martins, D. F.; Gerson, G. C.

Figura 1: Indicação das principais vias de circulação e dos elementos estruturante dos bairros

Campo Novo e Putiú e de seu entorno.
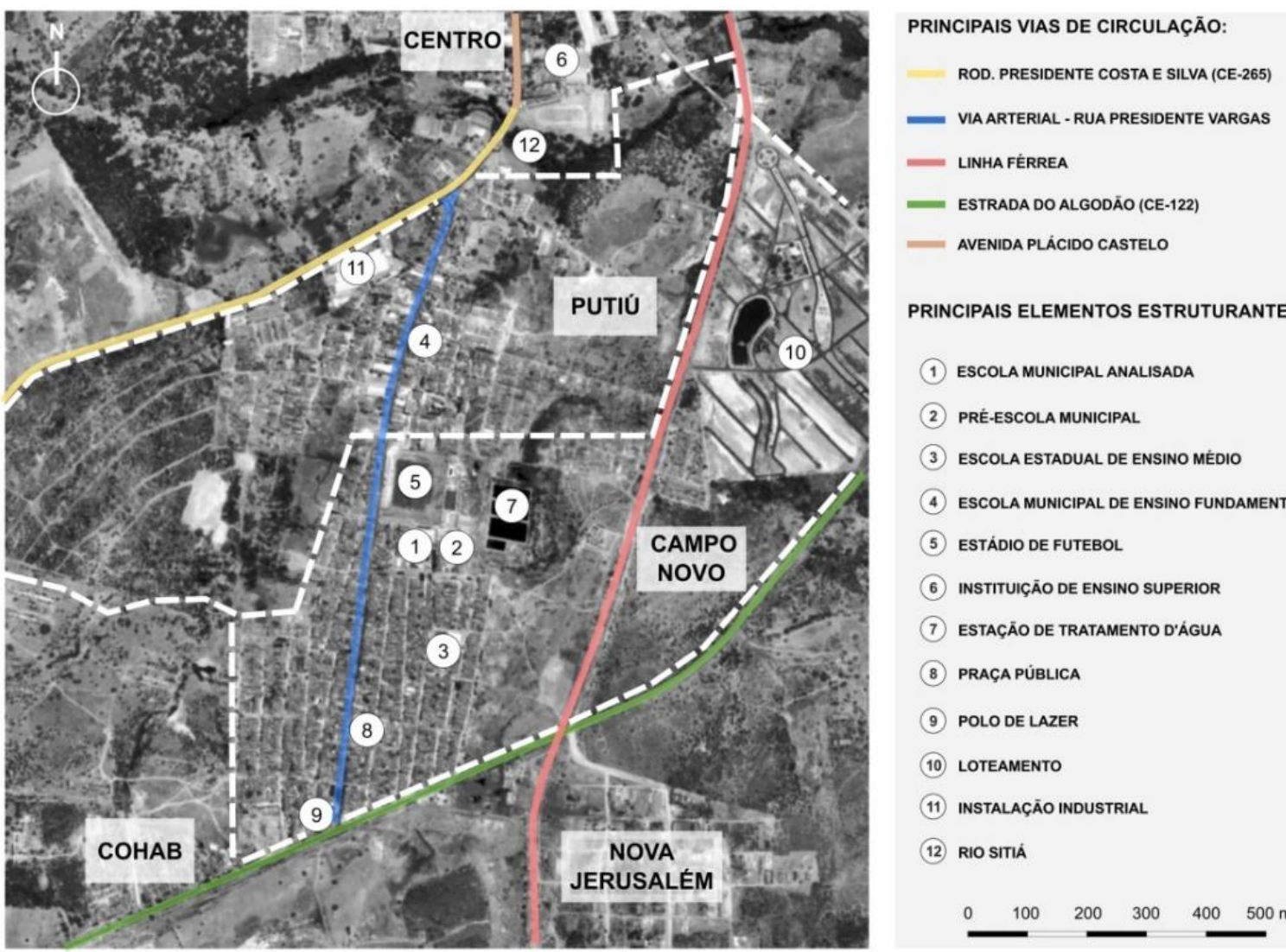

PRINCIPAIS ELEMENTOS ESTRUTURANTES:

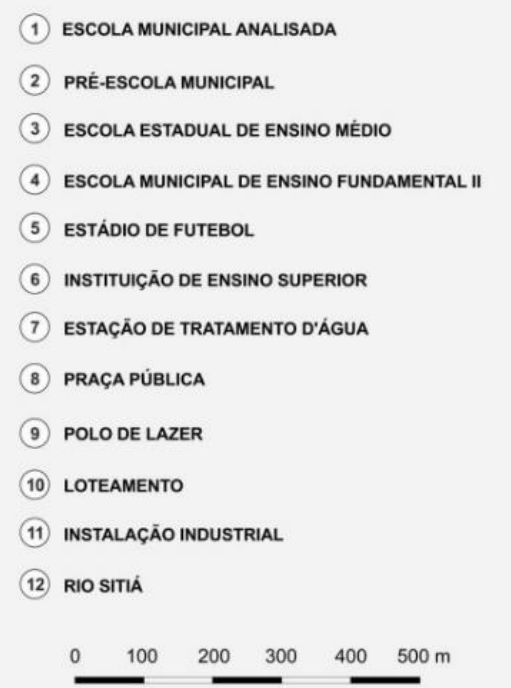

Fonte: Google Earth, adaptado pelo autor.

\section{A Escola Municipal de Ensino Fundamental I analisada e seu entorno}

Quanto à infraestrutura de educação, os bairros Campo Novo e Putiú possuem quatro escolas públicas e nenhuma de ensino privado, sendo três municipais (uma pré-escola, uma escola de ensino fundamental I e outra que funciona o ensino fundamental II) e uma estadual de ensino médio. A área foi estabelecida pela prefeitura como uma Regional Educacional do sistema da Secretaria de Educação do município. Como relatado, a Escola Pública Municipal de Ensino Fundamental I escolhida apresenta uma faixa-etária de alunos de 09 a 12 anos.

A instituição possui fácil localização no bairro e tem como marcos de referência o cruzamento da rua da escola (Travessa do Oliveira) com a Rua Presidente Vargas - reconhecida facilmente pelos moradores e com a proximidade do prédio com o estádio municipal de futebol - reconhecido por boa parte dos moradores da cidade. É importante salientar que no presente ano letivo de 2017, a escola possui 503 alunos no total, divididos em três anos de ensino: $4^{\circ}, 5^{\circ}$ e $6^{\circ}$ anos, possuindo 13 funcionários e 25 professores que trabalham nos turnos da manhã e/ou tarde.

Quanto à infraestrutura, a escola dispõe de dois pavimentos no seu bloco implantado no centro do terreno com a distribuição das seguintes áreas: educacional, administrativo, cozinha, refeitório e pátio central. Nos fundos do terreno, está localizada a quadra poliesportiva com construção posterior ao restante do prédio. $\mathrm{Na}$ lateral do terreno, próxima à Rua da Lavanderia, encontram-se duas salas de aula desativadas que eram usadas em um antigo projeto pedagógico. Destaca-se a grande quantidade de área não construída no terreno, que favorece a criação de espaços livres que podem vir a possibilitar diversas atividades pedagógicas e/ou recreativas.

Foram realizadas seis visitas à área de investigação, divididas entre os turnos da manhã e tarde, sendo quatro, exclusivamente direcionadas à escola e as outras duas intercalando entre a escola e o restante dos bairros. As duas primeiras visitas foram de reconhecimento da área a fim de extrair informações sobre a dinâmica local da escola. Nas duas visitas seguintes, foram aplicados o mapa cognitivo e o poema dos desejos com 26 alunos em dois dias diferentes e turnos também distintos. 
Figura 2: Zoneamento dos usos e espaços da Escola Municipal de Ensino Fundamental I.

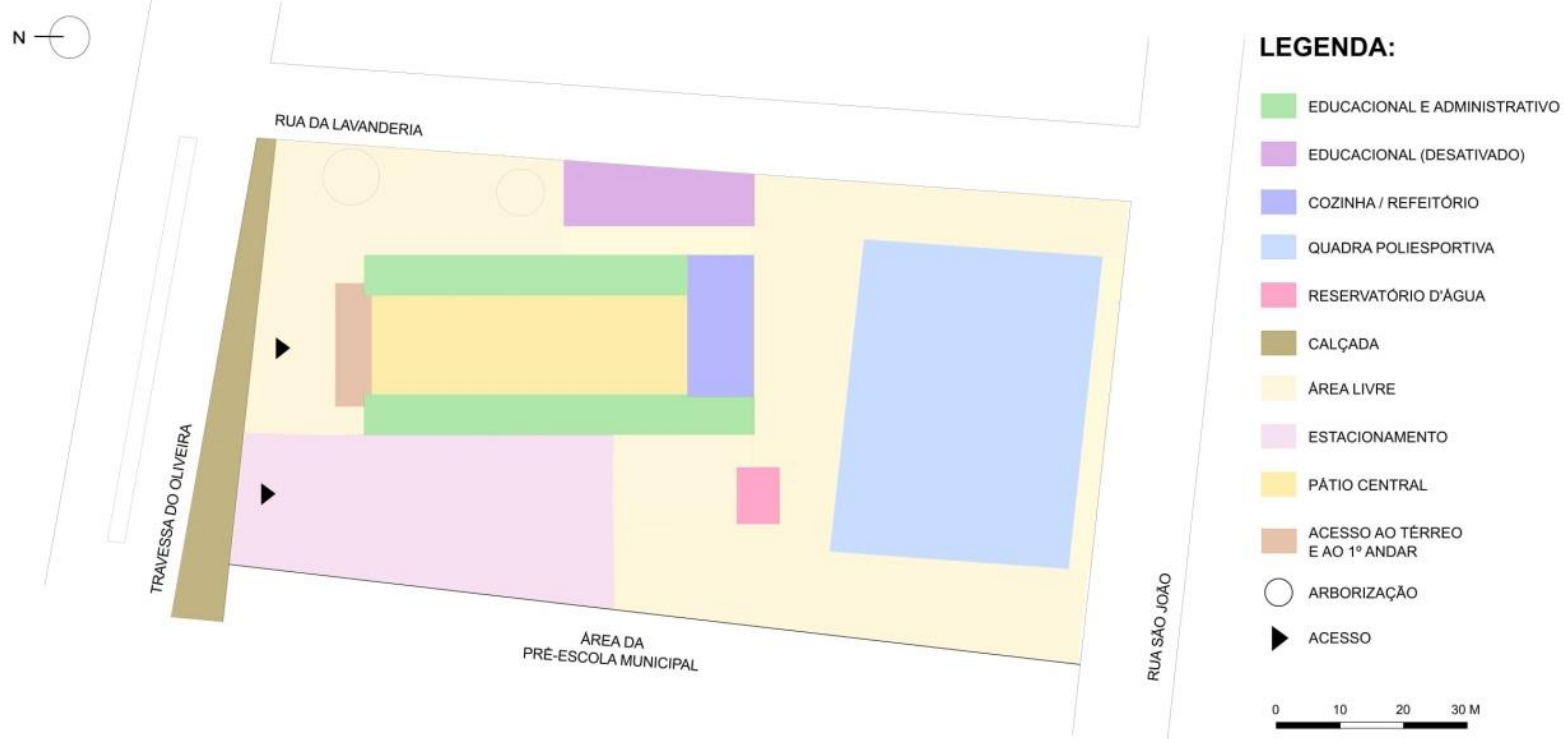

Fonte: O autor, 2017.

Na semana seguinte, ocorreu a elaboração do mapa comportamental também em dias e turnos diferentes, com o intuito de construir um panorama de como aconteciam os usos e apropriações das áreas livres da escola, com enfoque nas preferências ambientais e na dinâmica dos espaços. Os dois últimos contatos foram reservados a reconhecer a dinâmica do bairro a partir dos relatos dos alunos, gestores e professores, pois se pretendia conhecer os bairros a partir da visão dos moradores: das principais vias de circulação, as características mais marcantes e um pouco da realidade da vida cotidiana destes.

\section{CAMINHO CASA-ESCOLA: ELEMENTOS ESTRUTURADORES E PREFERÊNCIAS AMBIENTAIS}

Para compreender a percepção das crianças sobre o deslocamento entre a casa e a escola, foi realizado o mapeamento cognitivo que é um procedimento desenvolvido por Kevin Lynch e tem por objetivo compreender como o usuário ou um grupo entende e percebe uma determinada área. De acordo com Rheingantz et al (2009) esse instrumento registra, codifica e armazena diversos processos psicológicos em relação ao ambiente que os usuários estão inseridos, geralmente são expressos por meio de desenhos e/ou relatos orais sobre a imagem e os aspectos que os indivíduos têm sobre o contexto analisado.

O mapa cognitivo foi utilizado para identificar os principais caminhos dos alunos à escola e observar se existem marcos ou características mais relevantes que se repetem. Com isso, foi feita a seguinte pergunta para os participantes: "como é o caminho que você faz até chegar à escola?" As crianças responderam com o desenvolvimento de desenhos ou de forma escrita. A análise foi realizada a partir da identificação do nome das ruas que os alunos destacaram nos desenhos e a descrição oral destes, por exemplo, de centralidades, elementos ou vias de referência. O resulto gráfico foi à elaboração de um mapa síntese que espacializa os caminhos casa-escola no tecido urbano.

Para Lynch (2011, p.52), as vias de circulação são predominantes na imagem que a maioria das pessoas tem sobre a cidade, pois os habitantes as observam à medida que se locomovem $\mathrm{e}$, ao longo das vias, os outros elementos da cidade se organizam e se relacionam. Fato que foi comprovado no contexto analisado, em que a via é o elemento protagonista do desenho, sobretudo, ao apresentar componentes que a caracterize de forma mais detalhada em que a pavimentação é algo marcante no desenho (Figura 3) ou ainda o quanto os elementos que margeiam a via, como casas, árvores e comércios se tornam referenciais nas ilustrações (Figura 4).

Foram diversos os motivos apontados pelos participantes como determinantes para escolher um trajeto ao invés de outro: ruas mais calmas, com menos carros; ruas mais movimentadas pela diversificação dos usos do solo ou trajeto mais curto, por exemplo. Este percurso casa-escola é realizado, geralmente, na companhia de um dos membros da família - sendo escolhidos por eles; enquanto na volta da escola para casa é realizado com os outros alunos da escola, o que favorece a escolha destes, que optam por sombreamento e por locais com menor circulação de veículos, dentre outros. 
Martins, D. F.; Gerson, G. C.

Figura 3: Mapa cognitivo de criança de 11 anos - O protagonismo do tipo de pavimentação encontrado no percurso casa-escola.

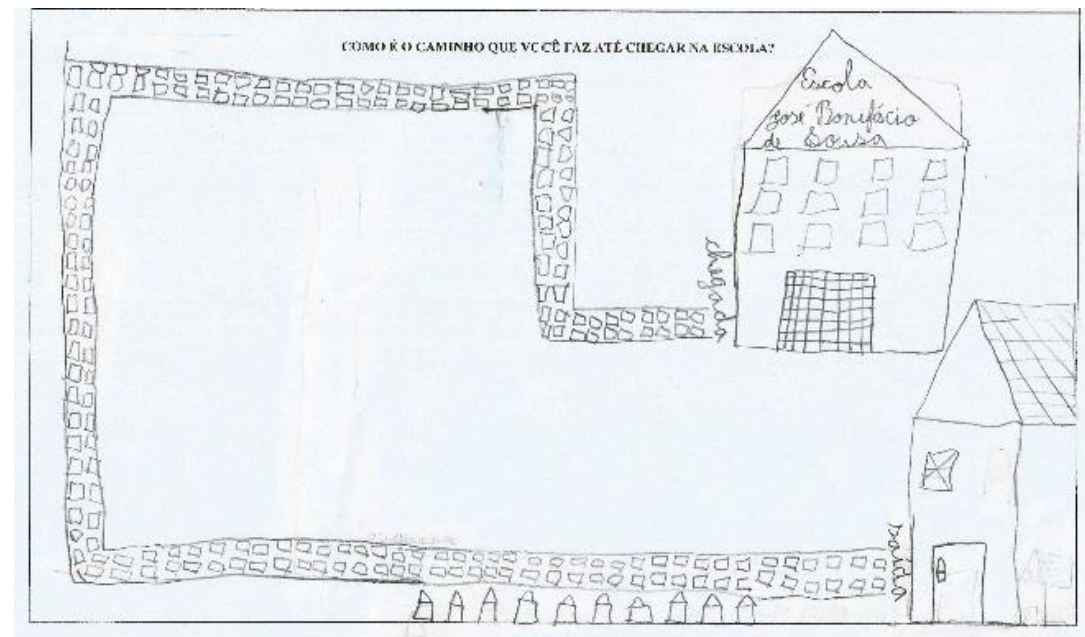

Fonte: O autor, 2017.

Figura 4: Mapa cognitivo de criança de 11 anos - A via como elemento estruturante e os usos do solo como destaque.

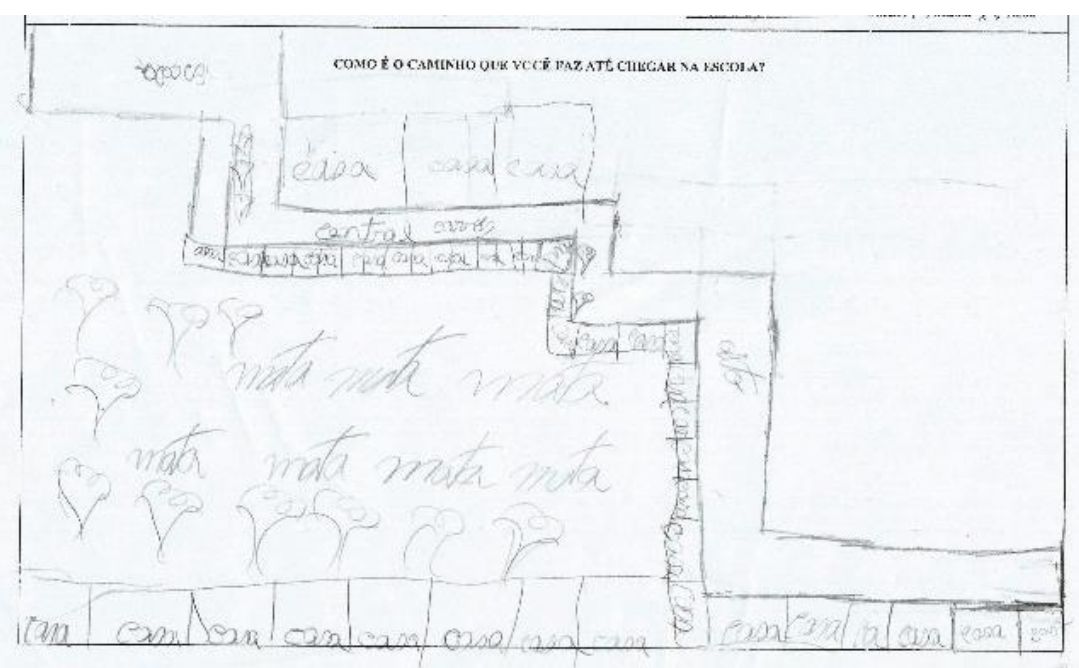

Fonte: O autor, 2017.

Dessa maneira, foi elaborado um mapeamento síntese dos trajetos casa-escola (Figura 5) visando compreender a localização dos participantes da pesquisa e conseguir ter uma amostra da realidade geral, além de tentar compor um panorama sobre quais são os acessos mais utilizados por eles para chegarem até a escola analisada. Ao se espacializar os resultados, a principal conclusão foi de que embora a escola esteja localizada no bairro Campo Novo, o público atendido por ela extrapola os limites do bairro. Assim, embora no início do desenvolvimento da presente pesquisa apenas o Campo Novo fosse o foco espacial do estudo, o resultado final deste instrumento fez com que houvesse uma reestruturação desta área de modo a abranger também o bairro Putiú, citado por algumas crianças.

Os caminhos mais utilizados são a Rua Presidente Vargas, a própria rua da escola (Travessa do Oliveira) e a Rua do Arame III. A partir da discussão sobre acessibilidade em suas vertentes tangível e intangível tratadas neste trabalho, mostra-se pertinente uma breve análise dos trajetos mais citados. A Rua Presidente Vargas, como "rua central" possui uma via asfáltica de dimensões adequadas; porém suas calçadas apresentam desníveis, obstáculos oriundos do comércio ou da má conservação, além de dimensionamento variável. Por se apresentar como a área de maior concentração do comércio local, constata-se poluição visual em diversos pontos pela falta de padronização de propagandas, o que desfavorece, por exemplo, a orientação por placas de sinalização de transeuntes que desconhecem a região. Um ponto positivo que facilita o acesso de todos, é o próprio desenho da via, que está centralizada no bairro, de modo que há um favorecimento dos pedestres, os quais optam por ruas com fluxo mais intenso de uso, mas que são próximas de vias locais. 
Figura 5: Espacialização do trajeto casa-escola nos bairros Campo Novo e Putiú.
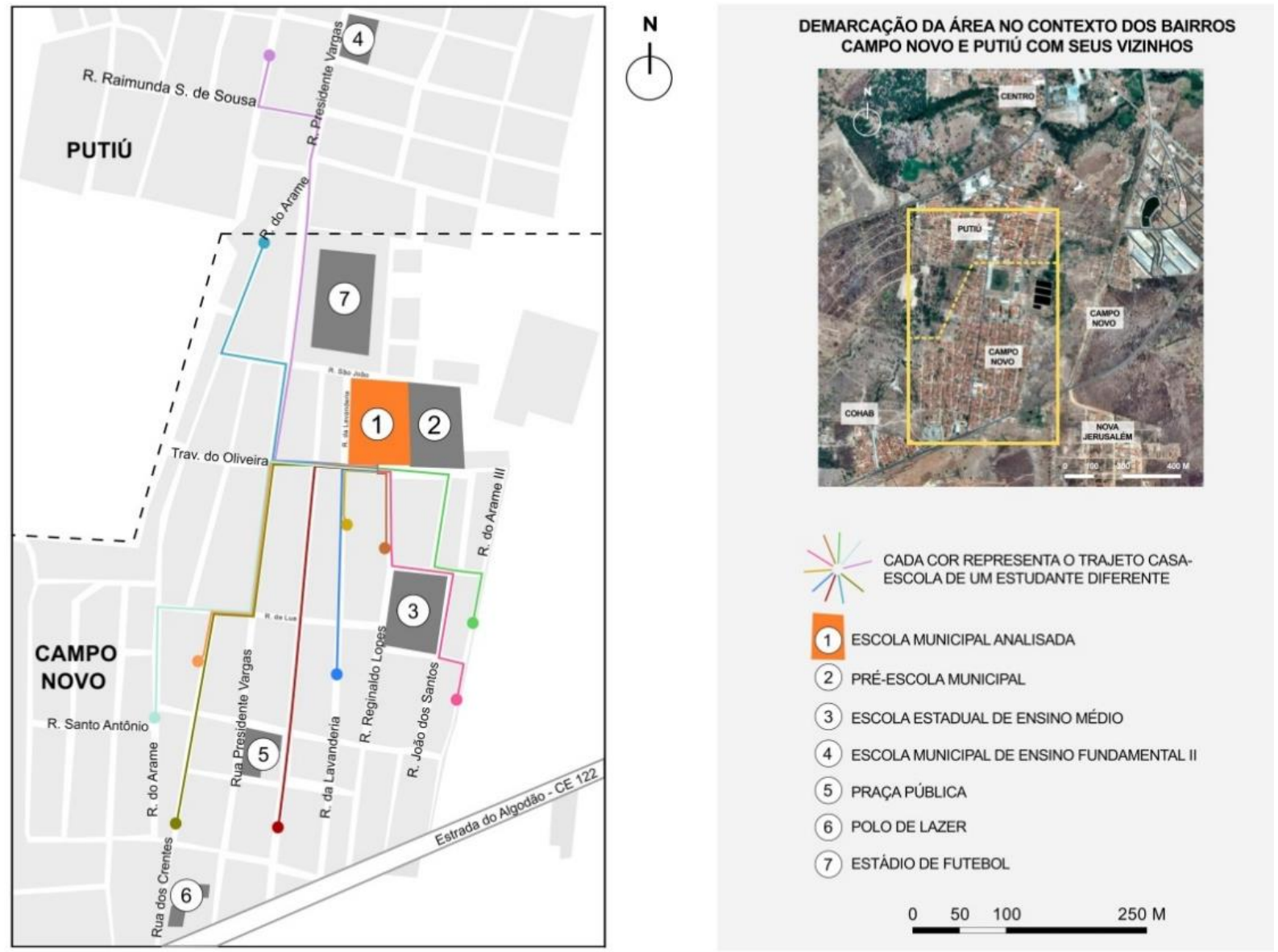

Fonte: Google Earth, adaptado pelo autor.

\section{PERCEPÇÃO SOBRE A ESCOLA: PREFERÊNCIAS E DESEJOS}

Para registrar a percepção das crianças sobre a escola, utilizou-se o poema dos desejos, definido por Rheingantz et al (2009) como uma possibilidade que o usuário do espaço tem de declarar de forma não estruturada e de livre expressão por meio de desenhos ou sentenças escritas, suas necessidades, sentimentos e desejos relativos ao ambiente analisado.

$\mathrm{Na}$ aplicação do instrumento, os alunos receberam uma folha com uma divisão de espaço para registrar a resposta para as perguntas: "qual o lugar que você mais gosta na escola?" E "o que você quer para a escola?" O intuito era descobrir os lugares que as crianças mais gostavam. A análise de conteúdo do poema dos desejos foi realizada de duas formas: quanto ao "lugar que mais gosta" buscou-se agrupar elementos que mais se repetiram a partir da compreensão do conteúdo do desenho e quanto ao desejo para a escola destacaram-se, textualmente, os principais.

A aplicação do poema dos desejos nesta pesquisa, buscou entender dois pontos: (1) quais são os lugares que os alunos mais gostam e (2) o que eles querem para escola. O poema dos desejos foi aplicado logo após o término do mapa cognitivo nos mesmos dias e turnos. Primeiro, todos os participantes responderam sobre qual lugar da escola eles mais gostavam. A grande maioria remeteu aos desejos momentâneos da criança; predominantemente, as áreas livres externas, como a quadra e as rampas, o que totalizou $69 \%$ das respostas, enquanto ambientes internos como a sala de aula foi indicada como a preferida de $31 \%$ dos entrevistados.

Como área de circulação, a escolha da rampa chama atenção por ser classificado como um dos locais que os alunos mais gostam (Figuras 6 e 7). Uma das interpretações possíveis e especulativas relaciona-se a ser um elemento pouco encontrado (ou não encontrado) em construções do bairro, sendo assim, distante da realidade das crianças, o que acaba por despertar sua atenção. Reforça-se essa ideia, o fato delas em nenhuma ocasião a terem nomeado como "rampa", variou entre "subida" e até "escada" (embora a escola não tenha presença de escada).

Figura 6: A rampa como lugar que mais gosta - criança de 10 anos. 


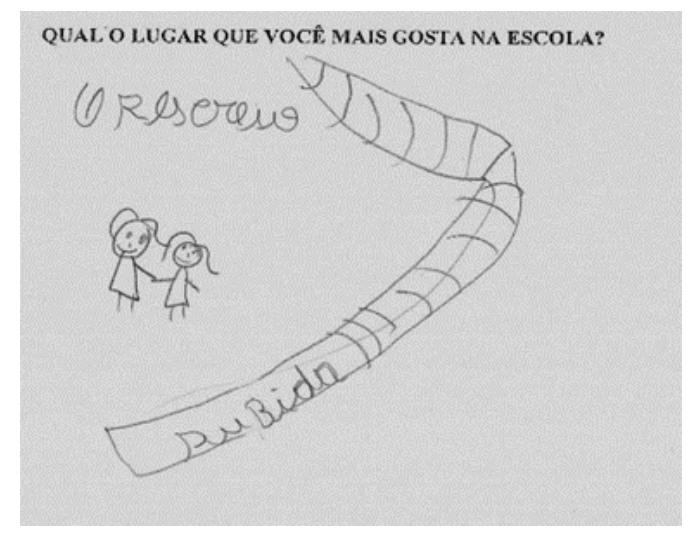

Fonte: O autor, 2017.

Figura 7: Vista da rampa da escola.

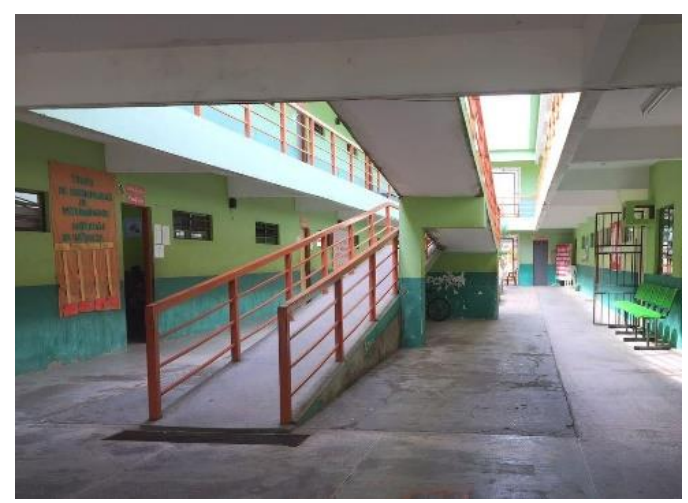

Fonte: O autor, 2017.

Quanto aos resultados em forma de desenhos ou textos que expressam o que as crianças querem para a escola, cerca de $25 \%$ dos participantes disseram que desejam que a escola possuísse um parque de diversões, $20 \%$ se reportaram a desejos de melhoria das relações pessoais com colegas e funcionários ou ainda aspiravam à vontades coletivas como a felicidade de todos; $15 \%$ possuíam o desejo de que na escola tivesse um jardim - possivelmente reflexo da vegetação não planejada presente na escola e da aridez de alguns espaços livres. As demais respostas tiveram uma grande diversidade como o desejo de uma aluna em ter uma quadra destinada somente para meninas, sob a justificativa que a quadra existente, só seria usada pelos meninos. Foi registrado também desejos como sala de brincadeiras e jogos; quadra de vôlei; melhoria nas salas de aula, comø a instalação de ar condicionado.

A escola, como já relatado, possui uma extensa área livre sem infraestrutura, essa questão é refletida claramente no desejo das crianças em terem um parquinho estruturado ou de terem contato com uma área de jardim bem colorido, como foi apontado por uma aluna (Figuras 8 e 9); provavelmente, um desejo que revela um ambiente atual pouco atrativo para as crianças, que prevalece à monotonia estrutural e estética.

Figura 8: Poema dos desejos de uma criança de 09 anos - Desejo de ter um parquinho.

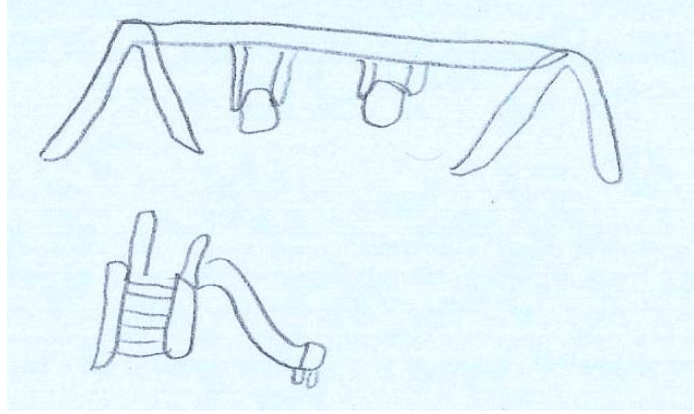

Fonte: O autor, 2017.

Figura 9: Poema dos desejos de uma criança de 11 anos - Desejo de ter um jardim. 


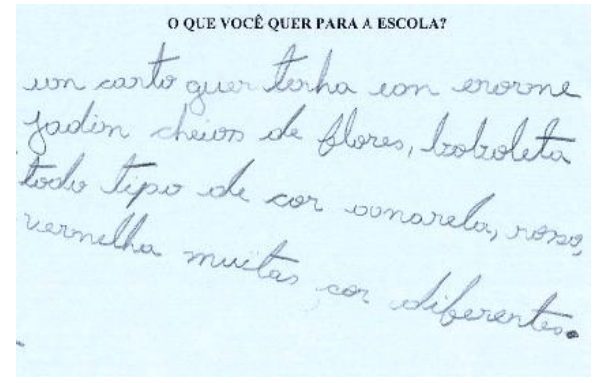

Fonte: O autor, 2017.

\section{ESPAÇOS LIVRES DA ESCOLA: FORMAS, USOS E APROPRIAÇÕES}

Para avaliação dos espaços livres da escola, foi usado o mapeamento comportamental que é uma forma de registro empírico que tem como objetivo identificar a percepção dos usuários sobre um ambiente. Com ele é possível entender como acontece à apropriação do espaço, ao avaliar os aspectos positivos e negativos do mobiliário e equipamentos existentes (RHEINGANTZ et al, 2009). As principais referências quanto à utilização deste instrumento são os estudos do Grupo de Arquitetura e Educação (GAE) da Universidade Federal do Rio de Janeiro (UFRJ), que possui um enfoque na avaliação pós-ocupação no ambiente educacional.

Tem-se por finalidade com o mapa comportamental, compreender como se estruturam os usos, apropriações e preferências ambientais nos espaços livres da escola, a fim de registrar a dinâmica existente. A síntese dos resultados deste instrumento foi espacializada numa representação gráfica em planta de implantação da escola com a criação de um zoneamento dos seus espaços livres em setores, de acordo com as características similares quanto aos usos, formas e apropriações (Figura 10). Buscou-se registrar a dinâmica dos espaços com destaque para os padrões de uso quanto ao gênero dos alunos, sobre as atividades desenvolvidas como brincadeiras direcionadas por um educador ou exercícios espontâneos dos alunos.

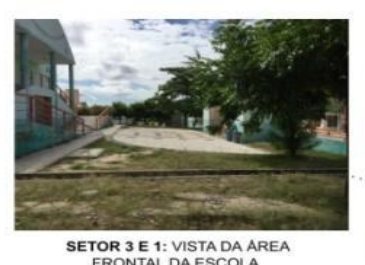

SETOR 3 E 1: VISTA DA AREA
FRONTAL DAESCOLA

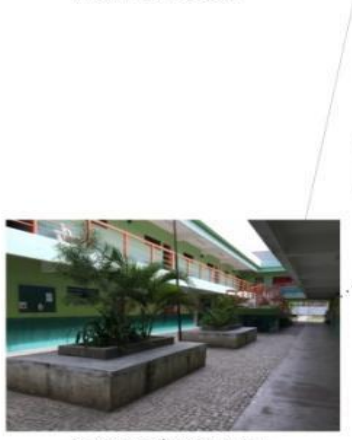

SETOR 4: PATIO CENTRAL

Figura 10: Divisão quanto aos aspectos físicos das áreas livres da escola.

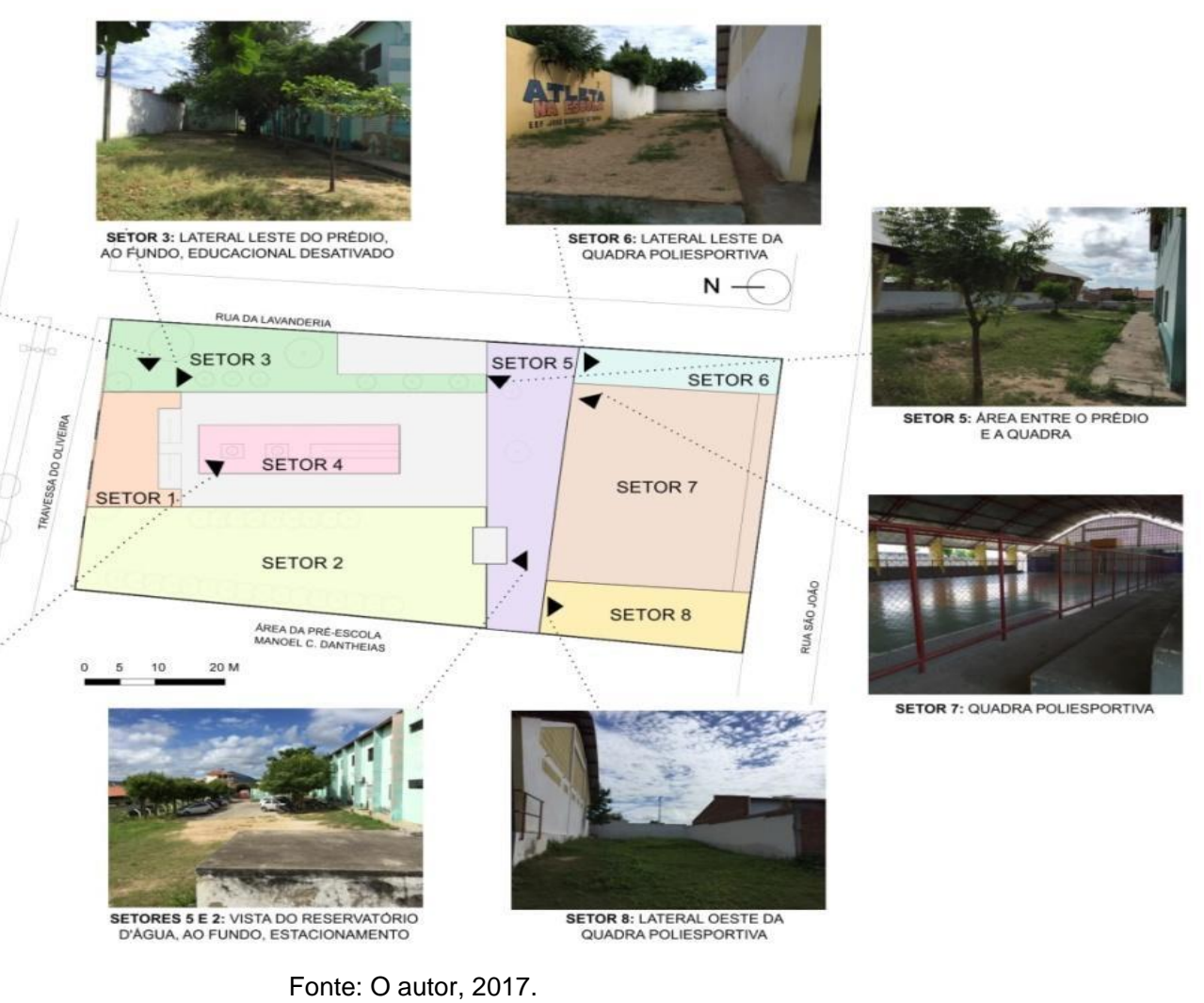

Primeiramente, foi realizada a observação no turno da manhã (Figura 11), em que existe uma intensa movimentação pelos setores 1, 3, 4 e 7. O setor 1 quanto a seus aspectos físicos, tem boa parte de sua extensão em pedra portuguesa sem grandes desníveis, porém com pouca arborização e não há mobiliário. 
Neste setor, não há tanta correria por sua extensão, provavelmente, por ser uma área de forte incidência do sol. As crianças menores ficam mais no movimento de subir e descer a rampa que é parcialmente coberta, enquanto as, aparentemente, mais velhas conversam na parte coberta.

No setor 3, que possui mais arborização e não recebe tanta incidência solar, recebe mais crianças que se movimentam por toda a área que tem muitos desníveis no terreno, favorecidos pela ausência de tratamento construtivo do espaço. As crianças desenvolvem brincadeiras coletivas ou mesmo individuais. No setor 4, do pátio central, o material do piso é pedra portuguesa, foram observados bancos para descanso, mas por conta da incidência solar, são pouco utilizados. As interações usuário-ambiente aconteceram basicamente no movimento de subir e descer a rampa e no caso do refeitório, por ter uma mesa relativamente grande com algumas cadeiras, acabou por atrair as crianças que preferiam ficar sentadas observando os demais ou ainda em conversas em grupo.

O setor 7 que compreende a área da quadra, é responsável por uma grande concentração de crianças, principalmente, de meninos. No dia da aplicação, havia uma atividade dirigida por um educador, com isso, não existia tanta correria ou barulho na área, predominantemente, quando existia, era em razão do jogo que acontecia. No tempo que alguns jogavam futsal, os demais aguardavam na arquibancada para jogar. A presença das meninas se restringia, basicamente, a arquibancada, reunidas em grupo sem muita interação com a atividade de futsal desenvolvida.

Os setores 2, 5, 6 e 8 praticamente não foram utilizados. O setor 2, é basicamente um espaço de transição no turno da manhã, este compreende o estacionamento, embora possua arborização em suas bordas, mas a parte central deste acaba por receber forte incidência solar, o que acaba sendo um empecilho para o uso pelas crianças. O setor 5 é mais uma área de transição do prédio da escola para a quadra, enquanto os setores 6 e 8 são, claramente, espaços residuais que têm sua utilização ainda mais comprometida pela não presença de mobiliário, pela presença de vegetação sem manutenção e pela grande quantidade de areia.

Figura 11: Mapa comportamental do turno da manhã das áreas livres da escola analisada.

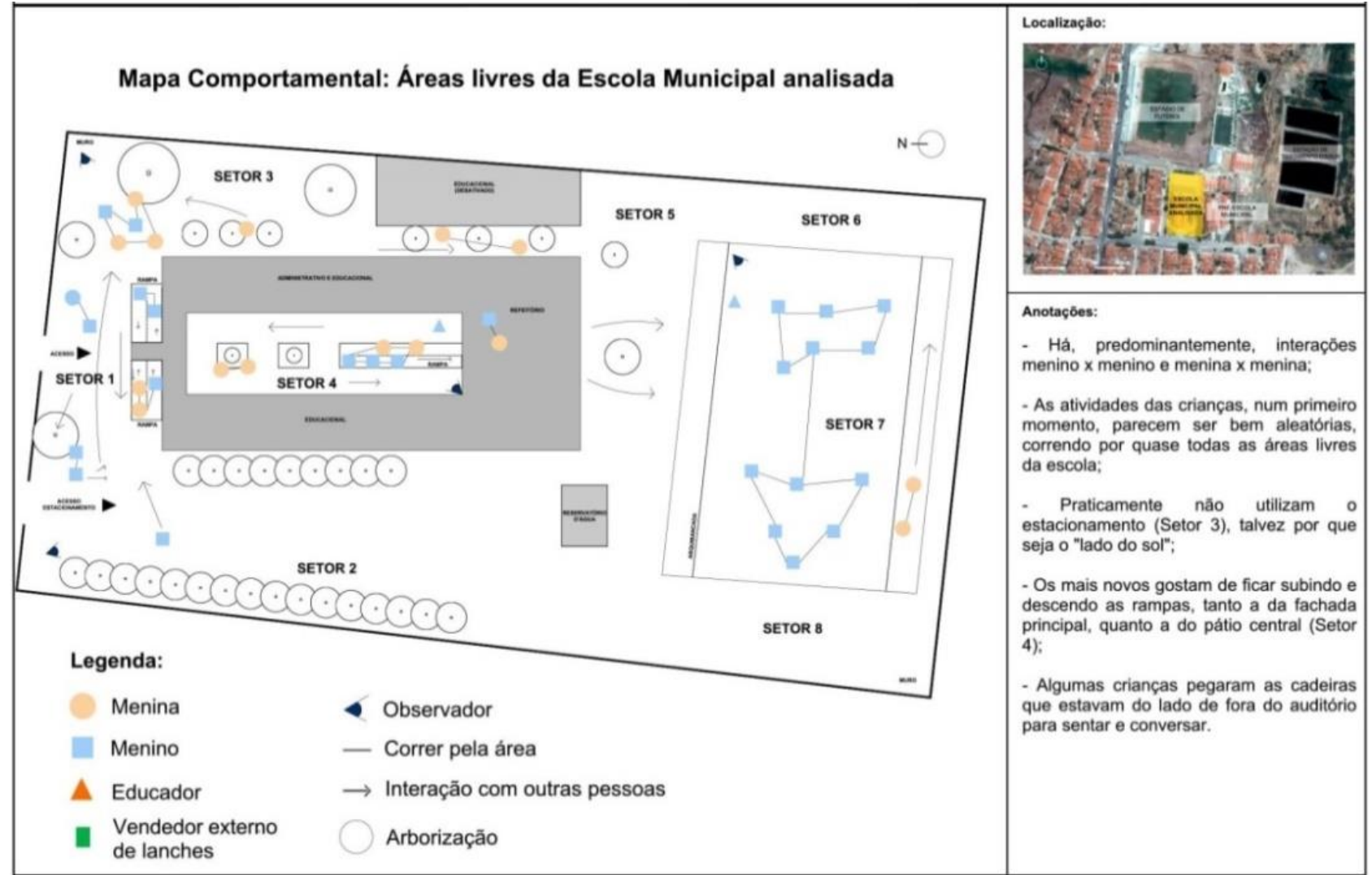

Fonte: O autor, 2017.

Algumas questões de uso e apropriação detectados pela manhã, também se repetiram no turno da tarde (Figura 12). Os setores mais usados foram 1, 2, 3, 4 e 7, a maior diferença entre a manhã e a tarde fica por conta da utilização da área do estacionamento (setor 2), provavelmente pela diminuição da incidência solar nesta área. Dessa forma, percebeu-se uma forte presença das crianças, que poderia se caracterizar como este sendo um ponto de encontro da escola. Enquanto as crianças mais velhas se reuniram em grupo debaixo da copa das árvores, em volta das motos e carros, as outras estavam sentadas na calçada; os menores 
Martins, D. F.; Gerson, G. C.

corriam pelo ambiente e outros desenvolveram uma atividade organizada por eles mesmos em grupo, numa espécie de competição de corrida.

Figura 12: Mapa comportamental do turno da tarde das áreas livres da escola estudada.

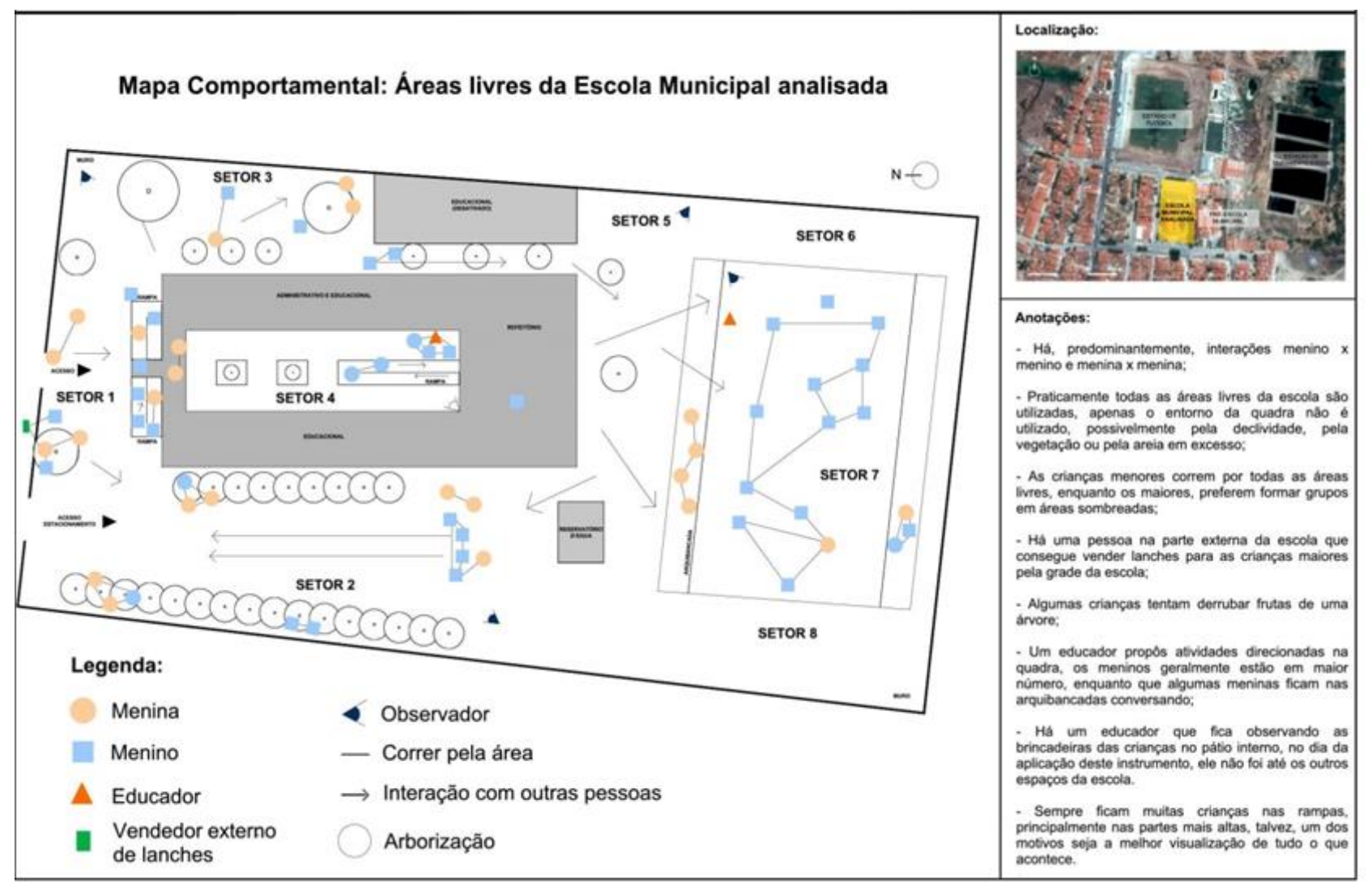

Fonte: O autor, 2017.

\section{CONSIDERAÇÕES FINAIS}

A aprendizagem promovida através do convívio com a diversidade, da socialização de maneira geral, não é menos educativa do que a aprendizagem ofertada no ensino formal. A escola ainda possui um papel muito presente no processo de formação das crianças. No entanto, não se deve cobrar que ela, sozinha, consiga suprir todas as lacunas do processo de desenvolvimento do ser humano. A escola pode ser vista como articuladora da vida urbana e palco do convívio social.

Com o referencial teórico foi possível investigar como o entorno da escola também possui um potencial educativo. Foi possível compreender as contribuições de uma possível integração física do ambiente externo (a comunidade) ao espaço interno (a escola) por meio dos espaços livres da escola e da cidade. Esses espaços demonstraram ser um provável meio de transição entre o externo e o interno, ao encarar a escola não como um espaço exclusivamente escolar, mas ao transformar-se numa área livre pública utilizável, também, pelos moradores dos bairros; num movimento integrador entre escola e comunidade.

Com a análise da área pode-se depreender como é a dinâmica dos espaços livres dos bairros e da escola investigada. A partir da avaliação dos resultados da aplicação dos instrumentos metodológicos foi possível observar a relação pessoa-ambiente no recorte em análise, focando nas crianças. Baseado nos apontamentos dos alunos foi possível perceber que as vias são elementos que norteiam a memória da criança, numa espécie de organizadora dos outros elementos que rodeiam essas vias, como por exemplo, os usos do solo, em que apareceram as casas e comércio; a presença de vegetação e, em alguns casos, detalhes da fachada frontal da escola e a figura humana.

Em relação à percepção dos alunos, os lugares preferidos e os seus desejos para a escola, destacam-se as áreas livres da instituição como elementos marcantes, pela representação e os discursos das crianças, o motivo permeia pela liberdade e as atividades de lazer possíveis nesses ambientes. Enquanto isso, os usos e apropriações desses espaços são bastante influenciados pelos aspectos físicos destes, algumas áreas sem nenhum mobiliário ou infraestrutura raramente recebem uso, como espaços residuais da escola. Outros 
fatores como insolação são determinantes para a forma como utilizam, configurando-se apenas como espaços de transição. As preferências são, geralmente, por elementos centrais como rampas e de espaços sombreados, o uso gira em torno de brincadeiras organizadas pelos alunos e conversas em grupo.

Quanto aos aspectos de acessibilidade, a infraestrutura dos espaços livres públicos dos bairros e os internos da escola encontram-se sem adequação mínima. Na parte interna da escola, há boas iniciativas, como a instalação de rampas e da pavimentação em alguns trechos. No entanto, ao se deparar com o entorno, as ruas são utilizadas mais como trajeto (pela necessidade de realizar um percurso) do que pelo prazer de caminhar ou da contemplação. Nelas e nas calçadas prevalece a dificuldade de locomoção tanto para adultos quanto para crianças, sejam pessoas com ou sem deficiência física ou mobilidade reduzida. Uma perspectiva interessante é a compreensão de que a acessibilidade pode ir além da presença de rampas ou pavimentação, pode ser tratada no que diz respeito a como ou quanto o espaço é convidativo, bem como no que se relaciona aos espaços (tanto da escola quanto dos bairros) serem mais ou menos favorecidos (ou desfavorecidos) em termos de atrativos.

Assim, se torna necessário considerar todas estas condicionantes a fim de compreender como a escola e seu entorno podem desenvolver seu potencial educativo através de seus espaços livres. No caso do entorno por meio das ruas, praças e vazios urbanos e no caso da escola, através das suas áreas livres, pode-se ir de encontro a uma forma de complementar a formação humana, através do reconhecimento destes espaços como áreas de estímulo à socialização, à autonomia e à cidadania.

\section{REFERÊNCIAS}

ALCANTARA, D. Abordagem experiencial e revitalização de centros históricos: os casos do corredor cultural no Rio de Janeiro e do Gaslamp Quarter em San Diego. Tese de Doutorado. Universidade Federal do Rio de Janeiro (UFRJ). Rio de Janeiro, 2008.

ALMEIDA, E. P.; GIACOMINI, L. B.; BORTOLUZZI, M. G. Mobilidade e Acessibilidade Urbana. II Seminário nacional de contrução sustentáveis (SNCS). Anais do..... Passo Fundo, RS.

AZEVEDO, G. A. N. et al. O lugar do pátio escolar no sistema de espaços livre do Rio de Janeiro: Resultados Preliminares. 2011. Disponível em: <http://quapa.fau.usp.br/wordpress/wp-content/uploads/2016/03/O-lugar-do-p\%C3\%A1tio-escolarno-sistema-de-espa\%C3\%A7os-livres-do-Rio-de-Janeiro-resultados-preliminares.pdf> Acesso em: 18 de abril de 2017.

AZEVEDO, G. A. N.; FARIA, J. R. F.; PEREIRA, F. R. Q. Do espaço escolar ao território educativo: o lugar da arquitetura na conversa da escola de educação integral com a cidade do Rio de Janeiro. In: 7 PROJETAR. 2015. (Org.). Projetar: Desafios e Conquistas da Pesquisa e do Ensino de Projeto. Anais do ..... Rio de Janeiro: Virtual Científica, 2015, p. 1-15.

DIAS, M. S.; FERREIRA, B. R. Espaços públicos e infâncias urbanas: a construção de uma cidadania contemporânea. Revista Brasileira de Estudos Urbanos Regionais, v.17, n.3, p.118-133, Recife, Set./Dez. 2015.

FARIA, B. G. de. A conversa da escola com a cidade: A produção de territórios educativos. São Paulo: Instituto Tomie Ohtake, 2017. Disponível em: <http://premioterritorioseducativos.org/Home/About>. Acesso em: 15 de fevereiro de 2017.

FREIRE, P. Pedagogia da autonomia: saberes necessários à prática educativa (Coleção Leitura). São Paulo: Paz e Terra, 1996.

GADOTTI, M. A questão da educação formal/não-formal. 2005. Disponível em: <http://www.vdl.ufc.br/ solar/aula_link/lquim/A_a_H/estrutura_pol_gest_educacional/aula_01/imagens/01/Educacao_Formal_Nao_Formal_2005 .pdf>. Acesso em: 8 de fevereiro de 2017.

A escola na cidade que educa. Cadernos Cenpec: educação e cidade, n. 1, p. 133-139, 2006. Disponível em: <file:///D:/Documentos/Downloads/caderno-cenpec-1.pdf>. Acesso em: 23 de fevereiro de 2017.

GEHL, J. Cidade para pessoas / tradução Anita di Marco. 1. ed. - São Paulo: Perspectiva, 2013.

GRINOVER, L. A hospitalidade urbana: acessibilidade, legibilidade e identidade. In: Revista Hospitalidade, São Paulo, ano III, n. 2, p. 29-50, 2. sem. 2006.

HAIASHIDA, K. A. Quixadá: Centro Regional de Convergência e Irradiação da Educação Superior (1983-2013). Tese de Doutorado. Universidade Estadual do Ceará (UECE). Fortaleza, 2014.

INSTITUTO BRASILEIRO DE GEOGRAFIA E ESTATÍSTICA (IBGE). Censo demográfico - Amostra populacional. IBGE, 2010. Disponível em: <http://cidades.ibge.gov.br/xtras/perfil.php?lang=\&codmun=231130\&search =ceara|quixada . Acesso em: 2 de março de 2017.

KOWALTOWSKI, Doris C. C. K. Arquitetura escolar: o projeto do ambiente de ensino. São Paulo: Oficina de Textos, 2011. LYNCH, K. A imagem da cidade. São Paulo: Editora Martins Fontes, 1997.

MARTINS, Valéria Roma. O lugar do pátio escolar: reunindo descobertas produzidas na observação de quatro escolas públicas do município do Rio de Janeiro. Dissertação (Mestrado em Arquitetura). Rio de Janeiro: UFRJ/FAU, 2013. 
NASCIMENTO, A. Z. S. do. A criança e o arquiteto: quem aprende com quem? Dissertação (Mestrado em Paisagem e Ambiente). Universidade de São Paulo. São Paulo, 2009.

PIZZOL, K. M. S. de A. Uso e apropriação dos espaços livres públicos e informais de uma área urbana em João Pessoa - PB. Dissertação (Mestrado em Desenvolvimento e Meio Ambiente). Universidade Federal da Paraíba, João Pessoa, 2005.

QUIXADÁ. Lei 1903, de 14 de abril de 2000: Dispõe sobre o Plano Diretor de Desenvolvimento Urbano de Quixadá P.D.D.U e dá outras providências. Quixadá, 2000.

OLIVEIRA, C. O ambiente urbano e a formação da criança. São Paulo: Aleph, 2004.

REIS-ALVES, Luiz Augusto dos. O que é o pátio interno? (Parte 2). Disponível em: <http://www.vitruvius.com.br/ revistas/read/arquitextos/06.064/425>. Acesso em: 12 de abril de 2017.

RHEINGANTZ, P. A. et al. Observando a qualidade do lugar: procedimentos para a avaliação pós-ocupação. Rio de Janeiro: Universidade Federal do Rio de Janeiro, Faculdade de Arquitetura e Urbanismo, Pós-Graduação em Arquitetura, 2009.

SAVI, A. E.; RECH, G. R. da F. Apropriação espacial das crianças - Um estudo ergonômico no pátio escolar. Estudos em Design, v.23, n.3 de 2015.

\section{NOTAS}

${ }^{1}$ A pesquisadora Kowaltowski (2011) se destaca na utilização do poema dos desejos em estudos relacionadas à arquitetura escolar na tentativa de compreensão da visão dos estudantes sobre o espaço. Enquanto isso, a arquiteta Oliveira (2004) busca entender a apreensão espacial de crianças sobre a vida urbana.

${ }^{2}$ Os espaços livres são compreendidos nesta pesquisa de acordo com os estudos de Pizzol como sendo divididos em três tipos: de recreação (praças, pátios e parques), de circulação (passeios públicos e ruas) e espaços livres potenciais (terrenos vazios ou recantos de calçadas, dentre outros).

NOTA DO EDITOR (*) O conteúdo do artigo e as imagens nele publicadas são de responsabilidade do(s) autor(es). 